\title{
Awareness of Green Marketing in Retailing and its Impact in Environment
}

\author{
G. Deepalakshmi
}

\begin{abstract}
Green marketing refers to the process of selling goods or services based on environmental benefits. Green selling is very much significant for a number of reasons from eliminating extravagance and to educate all the consumers about maintaining the product or services eco-friendly. Objective of the studyis to identify the awareness of green marketing among retailers and to analyses the impact of green marketing on environment. This study is a quantitative type of research and it involves a descriptive research design. Quantitative research is obtained based on the structured questionnaire framed. Researcher has taken Primary Data through Questionnaire and Secondary Data through Journals, Magazines and Internet. Researcher Used Bar Diagram, Pie Diagram and Chi-Square Analysis for Interpretation.
\end{abstract}

Keywords: Awareness, Environment, Green Marketing, Impact, Retail

\section{INTRODUCTION}

Green marketing refers to the process of selling products or services based on ecological benefits. Green marketing is very much significant for a number of reasons from eliminating extravagance and to educate all the customers about maintaining the product or services eco-friendly. The products produced by the producer with the concept of green marketing will be energizing the prediction of better alternatives, high quality of product or services, preserve the environment and save the time and cash of the stakeholders. Waste contributor from the pollution increases greenhouse gas which effect the increase in global warming. We as a producer concentrating on green marketing should concentrate on five R's which are "Refuse, Reduce, Recycle and Rot".

Green marketing concept among the producer in recent years are becoming more popular as it ensures long-term growth and by the same time it is contributing towards higher profitability. In the early stage of producing the product with the idea of green marketing it seems that the cost of producing the product is little higher but by later days it saves money and it helps company to selling their product and service care the benefit of surroundings as a whole and producing the product the product accordingly.

\section{ENVIRONMENTAL ISSUES}

Environmental issues have gained more importance in business and it threat more of the common citizen and business houses. All are worked about this and more particularly deterioration of oxygen level in one atmosphere. As all are not considering environment issues as any part this raises the problem of global warming. Business houses

Revised Manuscript Received on December 30, 2019.

Dr. G. Deepalakshmi, Head, Department of Business Administration, Marudhar Kesari Jain College for Women Vaniyambadi - 635 751, Tamil Nadu, India. and corporates are marketing products which may came some environmental issues. It is directly or indirectly effects the environmental issues. As a result Indian literature and urban consumers are getting more importance towards green products. Result of this is that all the business houses have better the rate of target consumers who are anxious about the green atmosphere.

\section{III.GREEN MARKETING ORIGIN}

Green marketing is the promotion of products that are reputed to be environmentally in safe hands. Similar stipulations which are equivalent to Green selling or environmental selling or ecological marketing. Business houses have in use green market as a part of their tactics. They are choosing green market as their system, polices and product due to some of the pressure from the consumer business partner, regulator, civilian group and the stakeholder. Business houses have idea towards the environment and that put the seed towards green marketing.

\section{IV.MEANING OF GREEN MARKETING}

Green or ecological marketing consists of all actions planned to generate and aid any exchanges proposed to satisfy individual needs or wants, such as the satisfaction of these requirements and which wants occurs with minimal detrimental impact on the expected environment.

\section{Constraints in Implementing Green Marketing:}

In many Corporate use green marketing as an effort to focus on price tag or profit related issues. In implement green marketing there are many constraints faced by the cooperates. In that lack of consumer awareness stands first, all the consumer are not completely aware of green marketing they are arising some of the unwanted Questions to the marketers who are practicing green marketing. Financial constraints stands the next problems for the corporate because all the firms will not be having same financial strengths. All the firms will not be having well furnished research and development cell, so lack of scientific knowledge is also the greater problems. Above all lack of stringent rules and spirited pressure is a greater constraints all the firms are facing while practicing.

\section{Important Four P's of Green Marketing:}

Main four P's green marketing are Production, Price fixing, Place choosing and Promotion activities. All the above P's are the core Ps which are common for even general marketing.






\section{Awareness of Green Marketing in Retailing and its Impact in Environment}

\section{Production:}

The business firm should concentrate more on produce the product with more crash on customers than the competitor. The basic for this is to recognize customer ecological needs and then they need to develop the products accordingly to satisfy the needs customers.

\section{Price Fixing:}

Environmental profit is an added bonus. This is the deciding dynamic between firms products and quality of the products produced. Consumers will often buy any goods with high price. When there is the chance of getting any additional product value on the same product they are buying.

\section{Place Choosing:}

Green products are positioned mostly in the common selling place. A small number of customers will go out of market place and they are buying green product very soon for the sake of unawareness that the product are in common market place. Place chosen for green marketing are emphasizing in store promotion, visually by attractive displays, recycling the resources and more interest on environment benefits.

\section{Promotion Activities:}

Green marketing is reinforcing environmental trustworthiness by using renewable marketing and communication techniques and practices. Promotion of green marketing includes advertising activity, publicity, sales promotion, direct marketing and on point of purchase promotions.

\section{Reasons towards "Go Green".}

All the firms decide to go green their systems, policy and products due to the pressure they are facing from the customer side. Other than the above there are many reasons they are.

- Green policies will always helps the firm reducing the cost of the products producing.

- Green firms shall shape all these products for future reputations and can concentrate on reaping on the same products can make it as advantage in the future also.

- Green Marketing will always take the firm towards building strong image in the minds of the consumers as they are given importance.

- Socially responsible firms are getting leverages when they are entering into foreign countries for exporting their products.

- Many of the firms are using Green marketing as marketing tools they are operational in the field without promote the real truth of it.

- Government law in most of the civilized countries, protect the consumer and the environment from dangerous goods or product produced by the firm.

- Government established several regulations to control the harmful waste product by the firm and they even produce environmental license to make all the firm towards soundly responsible.

- Competitive pressure is also another reason for which firm goes towards green marketing.
- Cost or profit are the major issue faced by the firm. In some cases disposal of waste is the major issue so the firms are reexamining the process of their production and they are trying to concentrate on the minimizing the waste products and utilizing the waste products as inputs of production for some other firm.

- Challenge faced by the firm on green marketing there is the certification need for the organic product checking. There is lack of standardization is the green marketing. Some regulatory bodies are to be involved in providing certification for green products. There should be proper standard quality control for labeling and licensing for all the products are under one roof of green marketing.

- Green marketing is the fresh concept. All the consumers are not much known towards environment safety and even the treats they use to follow on the products. Many consumer know about many things but they are not much on green marketing.

- All the firm faces problems in investing money in the business firm supporting green marketing. They are expecting immediate result for the investment they made but that is not possible care of green marketing as it is of made of long term benefit on investment opportunity. Firm are very ugly towards their return on investments. They re------ lot of patience and they need to ensure that there should be no immediate result for the investment made.

\section{V.RULES OF GREEN MARKETING}

The certain rules to be followed to implement green marketing in the business they know your customers thus is concerned on the knowing their customer and their issues. This concept attempts the marketing to attempt on customer issues and problems. Next rule is that to educate their customer that the attempt take by the corporates is to safeguard the environment and for its safety.

Business firm should follow almost genuinely and should follow transparency in following all attempts like green marketing Campaign, business policies for environment affairs. Reassuming the buyer is the next rule to be followed customer must be believe that the product performance should not be name sake like environment friendly.

Fixing on higher price is the next rule to be followed that means the price should ensure on high quality ingudiants. All the marketers should try to give their customer opportunity to participate in the polices they are framing for the benefit of the environment.

\section{VI.OBJECTIVES OF THE STUDY}

- To identify the knowledge of green marketing among retailers.

- To analyses the impact of green marketing on environment. 


\section{VII.SCOPE OF THE STUDY}

- To enable the stakeholders to identify about the uses of green marketing.

- This study enable to know about the retailers' alertness on green marketing.

- To enable all the producers to know about green marketing impact.

\section{VIII.LIMITATIONS OF THE STUDY}

- Research is done by researcher on 100 retailers only.

- This paper cannot be generalized with all the retailers.

\section{IX.RESEARCH METHODOLOGY}

This study is a quantitative type of research and it involves a descriptive research design. Quantitative research is obtained based on the structured questionnaire framed.

Research Type:

The qualitative research undergone by a review of existing literature. Quantitative research undergone by distribution of questionnaires to retailers.

\section{Sample Design:}

Convenience sampling method was undergone by the researchers for the research.

Sample Size:

Sample size for the research is 100 retailers.

\section{Data Collection Method:}

Researcher has taken Primary Data through Questionnaire and Secondary Data through Journals, Magazines and Internet.

\section{Tools Used:}

Researcher Used Bar Diagram, Pie Diagram and ChiSquare Analysis for Interpretation.

\section{X.DATA ANALYSIS AND DATA INTERPRETATION\& RESULTS}

Table - I: Period of Retailers Business

\begin{tabular}{|l|c|c|c|}
\hline \multicolumn{1}{|c|}{ Interval } & Response & Degree & $\begin{array}{c}\text { Cumulative } \\
\text { Degree }\end{array}$ \\
\hline $5-10$ & 60 & 216 & 216 \\
\hline $11-15$ & 23 & 83 & 299 \\
\hline $16-20$ & 10 & 36 & 335 \\
\hline $21-25$ & 5 & 18 & 353 \\
\hline $\begin{array}{l}\text { More than } \\
25 \text { yrs. }\end{array}$ & 2 & 7 & 360 \\
\hline
\end{tabular}

\section{Interpretation}

From the above table it is interpreted that $60 \%$ of people are busy in retail business for 5-10 years, 23\% of people are engaged in retail marketing for $11-15$ years, $10 \%$ of people are engage in retail business for $16-20$ years, $5 \%$ of people are in retail sector for $21-25$ years.

Table No. - II: Period of Retailers Awareness on Green Marketing

\begin{tabular}{|c|c|c|}
\hline $\begin{array}{c}\text { Retailers } \\
\text { interval }\end{array}$ & Response & Percentage \\
\hline $1-2$ & 44 & $62 \%$ \\
\hline $2-4$ & 18 & $30 \%$ \\
\hline $4-6$ & 4 & $8 \%$ \\
\hline TOTAL & $\mathbf{6 6}$ & $\mathbf{1 0 0 \%}$ \\
\hline
\end{tabular}

\begin{tabular}{|l|c|c|c|}
\hline $\begin{array}{c}\text { Retailers } \\
\text { Interval }\end{array}$ & Response & $\begin{array}{c}\text { Not } \\
\text { Response }\end{array}$ & Total \\
\hline $1-2$ & 44 & 18 & 62 \\
\hline $2-4$ & 18 & 12 & 30 \\
\hline $4-6$ & 4 & 4 & 8 \\
\hline TOTAL & $\mathbf{6 6}$ & $\mathbf{3 4}$ & $\mathbf{1 0 0}$ \\
\hline
\end{tabular}

The above data are actual frequency

Expected Frequency (data) Table

\begin{tabular}{|l|l|l|}
\hline $\mathbf{O i}$ & $\mathbf{E i}$ & $(\mathbf{O i}-\mathbf{E i}) / \mathbf{E i}$ \\
\hline 44 & 40.9 & 0.234 \\
\hline 18 & 21 & 0.428 \\
\hline 18 & 19.8 & 0.163 \\
\hline 12 & 10 & 0.4 \\
\hline 4 & 5.28 & \\
4 & 2.72 & 0.0 \\
\hline \multicolumn{2}{|l|}{ Total } & $\mathbf{1 . 2 2 5}$ \\
\hline
\end{tabular}

Degrees of Freedom

$\mathrm{v} \quad=1$

\section{Table Value}

At 5\% level of significance for 1 degrees of freedom the value from chi-square table is 3.84 .

\section{Inference}

Calculated value is not greater than table value. So HO will be accepted.

That is retailer undergoing business for long time are aware of green marketing.

Table No - III: Period of Retailers Business

\begin{tabular}{|c|c|c|c|}
\hline S. No & Interval & Response & Percentage \\
\hline 01. & $5-10$ & 60 & $60 \%$ \\
\hline 02. & $11-15$ & 23 & $23 \%$ \\
\hline 03. & $16-20$ & 10 & $10 \%$ \\
\hline 04. & $21-25$ & 5 & $5 \%$ \\
\hline 05. & $\begin{array}{c}\text { More than } \\
25 \text { Yrs }\end{array}$ & 2 & $2 \%$ \\
\hline \multicolumn{2}{|c|}{ TOTAL } & $\mathbf{1 0 0}$ & $\mathbf{1 0 0 \%}$ \\
\hline
\end{tabular}

\section{Interpretation}

From the above table it is interpreted that $60 \%$ of people are maintaining the retail business for 5-10 years, $23 \%$ of people are managing in retail business for 11-15 years, $10 \%$ of people are engaged in retail sector for $16-20$ years, $5 \%$ of people are engaged in retail business for 21-25 years. 


\section{Awareness of Green Marketing in Retailing and its Impact in Environment}

Table No - IV: Awareness of Green Marketing

\begin{tabular}{|c|c|c|c|}
\hline S. No. & Criteria & Response & Percentage \\
\hline 01. & Yes & 66 & $66 \%$ \\
\hline 02. & No & 34 & $34 \%$ \\
\hline \multicolumn{2}{|c|}{ TOTAL } & $\mathbf{1 0 0}$ & $\mathbf{1 0 0 \%}$ \\
\hline
\end{tabular}

\section{Interpretation}

From the above table it is interpreted that $66 \%$ of people are of green marketing and $34 \%$ of the people are unaware of green marketing.

Table No - V: Period of Retailers Awareness on Green Marketing

\begin{tabular}{|c|c|c|c|}
\hline S. No. & Interval & Response & Percentage \\
\hline 01. & $1-2$ & 44 & $66 \%$ \\
\hline 02. & $2-4$ & 18 & $27 \%$ \\
\hline 03. & $4-6$ & 4 & $61 \%$ \\
\hline 04. & $6-8$ & - & - \\
\hline 05. & $\begin{array}{c}\text { More than } \\
8 \text { yrs }\end{array}$ & - & - \\
\hline \multicolumn{2}{|c|}{ TOTAL } & $\mathbf{6 6}$ & $\mathbf{1 0 0 \%}$ \\
\hline
\end{tabular}

\section{Interpretation:}

The above table says the interval the retailers know about green marketing are 1-2 interval $66 \%$ of respondents, 2-4 interval are $27 \%$ of respondents, $4-6$ interval are $61 \%$ of respondents.

Table No - VI: Practices Encouraging Green Marketing

\begin{tabular}{|l|l|c|c|}
\hline S. No & \multicolumn{1}{|c|}{ Option } & Response & Percentage \\
\hline 01. & $\begin{array}{l}\text { Avoiding } \\
\text { Plastic bags }\end{array}$ & 38 & $57.5 \%$ \\
\hline 02. & $\begin{array}{l}\text { Using Paper } \\
\text { bags }\end{array}$ & 15 & $23 \%$ \\
\hline 03. & $\begin{array}{l}\text { Using solar } \\
\text { energy }\end{array}$ & 4 & $6 \%$ \\
\hline 04. & $\begin{array}{l}\text { Using LED } \\
\text { lights }\end{array}$ & 3 & $4.5 \%$ \\
Gifting Seed & 6 & $9 \%$ \\
\hline 05. & $\mathbf{6 6}$ & $\mathbf{1 0 0 \%}$ \\
\hline
\end{tabular}

\section{Interpretation:}

Theabove table represent the practices which are practicing by the retailers on green marketing. Majority of the retailers are avoiding plastic bags and instead they are using paper bags for the purpose of distributing the products.

Table No - VII: Percentage of Price Difference on Green Marketing

\begin{tabular}{|c|c|l|l|}
\hline S. No & Internal & e & Percentage \\
\hline 01. & $1-2 \%$ & 40 & $60.5 \%$ \\
\hline 02. & $2-3 \%$ & 17 & $26 \%$ \\
\hline 03. & $3-4 \%$ & 9 & $13.5 \%$ \\
\hline 04. & $4-5 \%$ & - & - \\
\hline 05. & $\begin{array}{c}\text { More Than } \\
5 \%\end{array}$ & - & - \\
\hline \multicolumn{2}{|r|}{ TOTAL } & - & $\mathbf{1 0 0 \%}$ \\
\hline \multicolumn{4}{|r}{} \\
\end{tabular}

\section{Interpretation:}

From the above table retailer say they have price difference in green marketing in different interval such as 1$2 \%$ are $60.5 \%$ of respondents, $2-3 \%$ are $26 \%$ of respondents, $3-4 \%$ are $13.5 \%$.

Table - VIII: Impact of Green Marketing in Environment

\begin{tabular}{|c|c|c|c|}
\hline S. No. & Criteria & Response & Percentage \\
\hline 01. & $\begin{array}{c}\text { Environment } \\
\text { Safety }\end{array}$ & 15 & $23 \%$ \\
\hline 02. & $\begin{array}{c}\text { Environment } \\
\text { Protection }\end{array}$ & 14 & $21 \%$ \\
\hline 03. & $\begin{array}{c}\text { Better and } \\
\text { healthy life }\end{array}$ & - & - \\
\hline 04. & $\begin{array}{c}\text { Customer } \\
\text { Satisfaction }\end{array}$ & 13 & $20 \%$ \\
\hline 05. & All the above & 24 & $36 \%$ \\
\hline \multicolumn{2}{|c}{ Total } & & $100 \%$ \\
\hline
\end{tabular}

Interpretation:

From the above table on impact of green marketing ,23\% of respondents say that Green marketing have impact on safety environment, $21 \%$ of respondents say that Green selling have impact on protecting environment, $20 \%$ of respondents say that Green promotion have impact on satisfying the customer and $36 \%$ of respondents say all the above have shock on Green marketing

Table - IX: Impact of Green Marketing in Developing Environment

\begin{tabular}{|c|c|c|c|}
\hline S. No. & Criteria & Response & Percentage \\
\hline 01. & CSR & 13 & $20 \%$ \\
\hline 02. & $\begin{array}{c}\text { Safety and } \\
\text { Security }\end{array}$ & 18 & $27 \%$ \\
\hline 03. & $\begin{array}{c}\text { Customer } \\
\text { satisfaction }\end{array}$ & 15 & $23 \%$ \\
\hline 04. & $\begin{array}{c}\text { Eco-friendly } \\
\text { Process }\end{array}$ & 20 & $30 \%$ \\
\hline 05. & Any other & - & - \\
\hline \multicolumn{2}{|r|}{} & $\mathbf{6 6}$ & $\mathbf{1 0 0 \%}$ \\
\hline
\end{tabular}

Interpretation:

From the table 20\% of the respondents says green marketing concentrate on CSR,27\% on safety and security,23\% for customer satisfaction $30 \%$ for Eco friendly process

Findings:

- $60 \%$ of the retailers are undergoing business for 5-10 years.

- $66 \%$ of the retailers are aware of green marketing.

- From Chi-square analysis the researcher shall drive the result as retailers undergoing business for long time are compulsory aware of green marketing.

- $58 \%$ of the retailers are avoiding plastic bags for distributing the products to consumers.

- $61 \%$ of the retailers increase the price on the product or services for undergoing the concept of green marketing. 
- All most all the retailers says that there is greater impact of green marketing on preventing environment.

Suggestions:

- All the retailers shall go for green marketing to prevent our environment with Eco-Friendly aspect.

- In the early stage it may be increasing the cost but of the sometime it is profitable. So, retailers concentrate more on it.

\section{Conclusion:}

Green marketing refers to uplift our environment ecofriendly. Retailers undergoing with the concept of green marketing have more impact on the society. Customers are satisfied with the concept of green marketing. Retailers undergoing business for long run are aware of green marketing.

\section{REFERENCES}

1. Donald R. Cooper and Pamela S. Schindler, Business Research method, 12th Edition, Tata Mc Graw Hill, 2010.

2. Duglas, J. Darymple, Marketing Management, John Wiley \& Sons, 7th edition, 2008

3. K. N. Krishnaswamy, Appa Iyer Sivakumar and M. Mathirajan, Management Research methodology, Pearson Education, New Delhi, 2009.

4. Micheal R. Czinkota \& Masaaki Kotebe, Marketing Management, Vikas Thomson learning, 2nd edition, 2001.

5. Paul Baisen et al, Marketing, Oxford University Press, 13th edition, 2008.

6. Philip Kortler and Kevin Lane, Marketing Management, PHI 13th edition, 2008 